\title{
Średniowieczne rycerstwo wielkopolskie do 1370 r. na przykładzie wybranych rodów
}

O rycerstwie wielkopolskim w średniowieczu napisano już sporo, ale jeszcze więcej pozostaje do zrobienia. Przed 1370 r. do grona rycerstwa wielkopolskiego zaliczali się przedstawiciele następujących rodów herbowych: Awdańców, Bylinów, Cielepałów, Doliwów, Drogosławiców, Dryjów, Godziębów, Grzymalitów, Jeleni-Niałków, Junoszy, Korabitów, Korzboków, Lasków, Łodziów, Nałęczów, Napiwoniów, Niesiobów, Nowinów, Okszów, Ołoboków, Pałuków, Pomianów, Porajów, Przosnów, Samsonów, Szaszorów, Świnków, Wczelitów, Wieniawitów, Wyskotów i Zarembów. W niniejszym tekście wskażę błędy i nieścisłości w Herbarzu średniowiecznego rycerstwa polskiego autorstwa Józefa Szymańskiego ${ }^{1}$, na przykładzie rodów Nałęczów, Wieniawitów oraz Grzymałów. Historycy korzystający z herbarzy mają tendencję do powoływania się na te dzieła, nie zaglądając wcześniej do źródeł. Należy jednak pamiętać, że nikt nie jest nieomylny i takie kompendia także zawierają błędy. Zatem, cytując herbarze, powiela się niekiedy owe nieścisłości, które mogą później funkcjonować jako fakt historyczny, a nie jako wytwór historiograficzny. Dlatego należy zawsze odnieść się bezpośrednio do źródeł, wykorzystując herbarz jako element pomocniczy.

Pierwszy z błędów, którym chcę się zająć, można znaleźć w części poświęconej herbowi i rodowi Nałęczów. Jest on opisany następująco: „w polu czerwonym pomłość srebrna w krąg o końcach związanych u dołu [...] Najstarsza pieczęć z 1293 r.”2 J. Szymański przy opisie najstarszej pieczęci rodu Nałęczów powołał się na Studya heraldyczne pióra Antoniego Małeckiego 3 . Jednak jeśli zajrzymy do nich, nic takiego na wskazanej stronie nie znajdziemy. Może autor pomylił strony? Może ta informacja znajduje się w opisie Nałęczów w pierwszym tomie dzieła A. Małeckiego ${ }^{4}$ ? Więc może J. Szymański

J. Szymański, Herbarz średniowiecznego rycerstwa polskiego, Warszawa 1993.

Ibidem, s. 192.

A. Małecki, Studya heraldyczne, t. 1, Lwów 1890, s. 132.

Vide ibidem, s. 97. 
lub wydawca herbarza pomylił tomy Studyów? I rzeczywiście na tej stronie $\mathrm{w}$ drugim tomie możemy znaleźć informacje o najwcześniejszych zachowanych pieczęciach ${ }^{5}$. Lecz nadal nic o pieczęciach Nałęczów. Wzmianki o nich znalazły się w tym dziele na stronie 160 drugiego tomu. Możemy tam przeczytać, że najstarsze pieczęcie pochodzą z 1310 r. oraz 1329 r., poza tym opatrzone są innym wizerunkiem ${ }^{6}$ (nota bene pieczęć Dobrogosta z Dzwonowa, z 1310 r., ma wizerunek jelenia ${ }^{7}$, a na pieczęci z 1329 r., należącej do Sambora z Nądni h. Samson, ukazana została odwrócona łękawica, z wyrastającym $\mathrm{z}$ niej $\mathrm{krzyżem}^{8}$ ). Natomiast najstarszy zachowany zabytek $\mathrm{z}$ wizerunkiem Nałęczów pochodzi z 1343 r. Skąd więc J. Szymański zaczerpnął tę informację? Może miał dostęp do jakiegoś dokumentu, który obecnie zaginął lub znajduje się w którymś z archiwów? Może pomyliła mu się data $1329 \mathrm{r}$. z 1293 r., gdy sięgał do swojej pamięci (są przecież podobne, lecz owa pieczęć należała do przedstawiciela rodu Samsonów). To jest pierwszy przykład, wskazujący na to, że zawsze warto weryfikować przypisy konkretnych prac i powoływać się bezpośrednio na źródła, a nie na opracowania.

Z kolei ród Wieniawitów J. Szymański opisał w następujący sposób: „w polu złotym czarna bawoła głowa $\mathrm{z}$ kolcem srebrnym”" . Wymienia on również inne warianty tego herbu, mianowicie na ołtarzu w kościele Wniebowzięcia NMP

Ibidem, t. 2, Lwów 1891, s. 132.

Ibidem, s. 160.

Kodeks dyplomatyczny Wielkopolski, t. 2, wyd. I. Zakrzewski, Poznań 1879, nr 937. Pieczęć ta pomogła K. Benyskiewiczowi uznać, że Dobrogost z Dzwonowa należał do rodu Jeleni-Niałków, autor jednakże popełnił błąd uznając Dobrogosta za Jelenia, bowiem od tego pnia rodu Nałęczów wywodził się Sędziwój Świdwa, który był niewątpliwie Nałęczem. Również późniejsza przynależność Dzwonowa do Nałęczów nie była nigdy kwestionowana, bowiem Dzwonowo na przełomie XIV i XV w. należało do Marcina, brata Sędziwoja Świdwy; cf. K. Benyskiewicz, Ród Jeleni-Niałków i jego rola w procesie jednoczenia państwa polskiego na przełomie XIII i XIV w., Poznań 2002, s. 15-16; J. Pakulski, Nałęcze wielkopolscy w średniowieczu, Toruń 1982, s. 39-40, tab. III; K. Górska-Gołaska, Dobra Nałęczów w Wielkopolsce w średniowieczu, „Studia i Materiały do Dziejów Wielkopolski i Pomorza” 1984, t. 15, z. 2, s. 191-192.

8 Kodeks..., nr 1101; F. Piekosiński, Pieczęcie polskie wieków średnich, Kraków 1899, s. 201, nr 342, fig. 225. Wydawca Kodeksu dyplomatycznego Wielkopolski, I. Zakrzewski, przy opisie dokumentu nr 1101, myli Wilisława z Samborem. W deskrypcji tegoż podaje, że zawieszona do dyplomu pieczęć należała do Wilisława, podczas gdy w suplemencie przy jej wizerunku widnieje opis: „S. Samborii Vatta de Nanden”, z błędną datą 1330 r.; cf. Kodeks..., t. 4, Poznań 1881, pieczęć XLV.

$9 \quad$ Cyt. za J. Szymański, Herbarz..., s. 289. 
w Książnicach Wielkich pole herbu miało być srebrne (chociaż nie znajdujemy takiego przedstawienia w herbarzu). Powołuje się przy tym na Katalog zabytków sztuki $w$ Polsce ${ }^{10}$. Jednak w tym przypadku występuje jeden mały mankament, a mianowicie - katalog ten posiada jedynie 62 ilustracje, rzeczywiście jest tam opisany kościół, ale w Kozienicach Wielkich, przy czym nie ma wzmianki o herbie Wieniawa, ani nawet o wspomnianym ołtarzu, a co za tym idzie, brak również informacji o predelli ${ }^{11}$. Inne źródła pozwalają stwierdzić, że w rzeczywistości herb istnieje na tejże predelli, ale pole tarczy jest tam złote ${ }^{12}$. W 2009 r. ołtarz przeszedł gruntowną renowację, lecz raczej nie zmieniano kolorów, tylko odnowiono go, co było celem całej operacji. Drugi problem, na który mogą natrafić badacze związany jest z godłem Wieniawitów. Jest ono w różnych źródłach opisywane bądź jako głowa bawoła (m.in. Bawola caput) $)^{13}$, bądź łosia (caput onagri) ${ }^{14}$, bądź żubra (zabrzinum caput $)^{15}$, bądź nawet tygrysa (caput tigridis) ${ }^{16}$. W omawianym herbarzu J. Szymański rozwiązał ten problem za pomocą metody statystycznej, gdyż uznał za obowiązujące godło z bawolą głową, gdyż je najczęściej wzmiankują źródła średniowieczne ${ }^{17}$. Dodać trzeba, że godło to opisywane było później w innych, nowożytnych już herbarzach, jako żubrza głowa (u Bartosza Paprockiego, Szymona Okolskiego i Kacpra Niesieckiego). Dziwne jest, że w tej kwestii nie zaufał J. Szymański Janowi Długoszowi, który w końcu pochodził z Wieniawitów, skoro pole złote tarczy herbowej podaje właśnie za nim ${ }^{18}$. Herb ten w wydaniu J. Szymańskiego jest więc kompilacją różnych zapisek. Nie

10 Ibidem, s. 289; J. Szymański powołuje się na Katalog zabytków sztuki w Polsce: województwo kieleckie, t. 3, z. 6, red. J. Łoziński, Warszawa 1958, s. 17, il. 76.

11 Cf. Katalog..., s. 16-17.

12 Aktualne zdjęcie ołtarza w kościele Wniebowzięcia NMP w Książnicach Wielkich dostępne jest na blogu pt. Patriota pejzażu, http://hanys1920.blox.pl/tagi_b/106211/ poliptyk-ksiaznicki.html [dostęp: 9.11.2014].

13 Starodawne prawa polskiego pomniki z ksiag rękopiśmiennych dotąd nieużytych główniej zaś z ksiąg dawnych sądowych ziemskich i grodzkich ziemi krakowskiej, t. 2, wyd. A. Z. Helcel, Warszawa 1870, s. 125, nr 807.

14 Materyaly do historyi prawa i heraldyki polskiej, wyd. B. Ulanowski, [w:] Scriptores rerum polonicarum, t. 9, Kraków 1886, s. 296, nr 70.

15 Klejnoty Długoszowe, wyd. M. Friedberg, „Rocznik Polskiego Towarzystwa Heraldycznego we Lwowie" 1930, t. 10, s. 63.

16 J. Długosz, Catalogus Archiepiscoporum Gnesnensium, [w:] Joannis Dlugossii Senioris Canonici Cracoviensis Opera omnia, t. 1, wyd. I. Ż. Pauli, Kraków 1887, s. 354.

17 Cf. J. Szymański, Herbarz..., s. 291, przyp. 4.

$18 \quad$ Ibidem, s. 291, przyp. 2. 
można oczywiście odrzucić teorii, że herb ewoluował, skoro późniejsze herbarze podają jako godło żubrzą głowę. Należy pamiętać, że w omawianych ramach czasowych żubry występowały jedynie w Puszczy Białowiejskiej, Niepołomickiej i lasach sandomierskich ${ }^{19}$, zatem Wielkopolanin lub mieszkaniec Kujaw mógł nie widzieć żubra. Czy tak rzeczywiście było, trudno dociec, gdyż ewolucje herbu nastręczają wiele problemów, zwłaszcza przy ubogim zasobie źródeł. Niemniej jednak żubr nie jest identyczny z bawołem, zatem jeśli herb nie ewoluował (czego nie wykluczam), to trudno umotywować w jakikolwiek inny sposób zapiski herbowe z „bawołem”.

Ostatnim już przykładem jest herb Grzymała. J. Szymański blazonuje go tak: „w polu złotym czerwony mur z trzema wieżami o trzech cieniach każda i otwartą bramą"20. Jednak oprócz „podstawowego" herbu podaje również odmiany tegoż, $\mathrm{w}$ różnych źródłach, tj. na fryzie w kaplicy św. Jakuba w Lądzie ${ }^{21}$, w tzw. Herbarzu Złotego Runa Jeana Le Fèvre'a de Saint Remy ${ }^{22}$, Armorialu Lyncenich ${ }^{23}$, Kodeksie $z$ Bergshammar $^{24}$ oraz Kronice Soboru $w$ Konstancji ${ }^{25}$. Należy więc pokrótce opisać wyżej wymienione źródła oraz ich ewentualne powiązania ze sobą. Zacznę od polskiego, zarazem najstarszego z nich, czyli fryzu w kaplicy św. Jakuba Apostoła w Lądzie, datowanego na połowę XIV w., a ufundowanego prawdopodobnie przez Wierzbiętę z Palowic, starostę generalnego Wielkopolski. Został tam zawarty program heraldyczny rycerstwa wielkopolsko-śląskiego, zawierający 21 herbów. Prawdopodobnie znalazły się tam rody, które popierały starostę Wierzbiętę $\mathrm{w}$ walce $\mathrm{z}$ konfederatami Maćka Borkowica, zauważalny jest bowiem

19 Cf. M. Krasińska, Z. A. Krasiński, European Bison. The Nature Monograph, Białowieża 2007, s. 48-52. ark:/12148/btv1b55009806h/ [dostęp: 9.11.2014]; herby polskie w tym herbarzu opisał Piekosiński; vide F. Piekosiński, Heraldyka polska wieków średnich, Lwów 1911, s. 364-377.

23 A. Heymowski, Herby polskie w brukselskim Armorial Gymnich, recte Lyncenich, „Studia Źródłoznawcze” 1985, t. 29, s. 95-124.

24 A. Heymowski, Herby polskie w sztokholmskim Codex Bergshammar, „Studia Źródłoznawcze” 1967, t. 12, s. 73-111.

25 Das Concilium So zu Constantz gehalten ist worden Des jars do man zalt von der geburdt vnsers erlösers M.CCCC.XIII Jar [...], Augsburg 1483, f. 366 http://tudigit. ulb.tu-darmstadt.de/show/inc-iii-55/ [dostęp: 9.11.2014]. 
brak przedstawienia heraldycznego m.in. rodu Nałęczów. Herb Grzymała przedstawiony jest tam następująco: „na białym polu czerwony mur o trzech basztach z krenelażem i bramą"26. Kolejne źródła pochodzą spoza Polski. Najwcześniejszy jest herbarz autorstwa Le Fèvre’a de Saint Remy, głównego herolda zakonu Złotego Runa, króla angielskiego i księcia Burgundii. $\mathrm{Na}$ pytanie, kto udzielił mu informacji na temat polskich herbów, odpowiedziano już w XIX w. ${ }^{27}$ Był to mianowicie Mikołaj Lasocki h. Dołęga. W 1434 r. Le Fèvre de Saint-Remy spotkał go w roli polskiego ambasadora w Arras. W wydaniu Franciszka Piekosińskiego herb ten jest opisany następująco: w czerwonem polu żółta Grzymałą ${ }^{28}$. Prawie współczesny jest flamandzki Armorial Lyncenich, więc korzystał on prawdopodobnie z tych samych źródeł co Le Fèvre de Saint-Remy. W tymże dziele herb Grzymała jest obecny w dwóch miejscach. Adam Heymowski opisał go pod numerem 18: „w polu czerwonym mur srebrny z trzema basztami, z których środkowa wyższa" 29 . Natomiast pod numerem 60 podał: „w polu czerwonym mur złoty z trzema basztami i bramą otwartą" ${ }^{30}$. Nieco późniejszy (być może burgundzki) jest Kodeks $z$ Bergshammar, ale również jego autor korzystał z tych samych źródeł. W tym kodeksie też mamy do czynienia z podwójnym wyobrażeniem herbu Grzymała. Ponownie u A. Heymowskiego, pod numerem 26, widnieje następujący opis: „w polu czerwonym mur srebrny z trzema basztami, z których środkowa wyższa" ${ }^{11}$, podczas gdy pod numerem 67 mamy, co następuje: „W polu czerwonym mur złoty z trzema basztami i bramą otwartą"32. Z kolei Kronika Soboru w Konstancji, wydana w Augsburgu w 1483 r. przez anonimowego autora, ale prawdopodobnie napisana przez Ulryka von Richental ok. 1413 r. i wzbogacona innymi informacjami przez wydawcę ${ }^{33}$, zawiera inny jeszcze wizerunek herbu: „w polu błękitnym czerwony mur o trzech blankowanych wieżach i złota otwarta brama".

Jak można zauważyć, herb Grzymała ma wiele wariantów. W Armorialu Lyncenich i w Kodeksie z Berghammar opis ten jest identyczny (chociaż trzeba pamiętać, że polskie herby w obu herbarzach opracował ten sam autor

\footnotetext{
J. Łojko, Fryz heraldyczny..., s. 136.

27 L. Larchey, Armorial ancien équestre de la Toison d'or et de l'Europe au XV'siécle, Paris 1890, s. XI.

28 Cyt. za F. Piekosiński, Heraldyka..., s. 373.

29 Cyt. za A. Heymowski, Herby polskie w brukselskim Armorial..., s. 103.

30 Ibidem, s. 110.

31 Cyt. za A. Heymowski, Herby polskie w sztokholmskim Codex..., s. 87.

32 Ibidem, s. 95.

33 H. Polaczkówna, Najstarsze źródła heraldyki polskiej, Lwów 1925, s. 2-10.
} 
- Adam Heymowski). Źródła te musiały więc być powiązane ze sobą oraz z Herbarzem Złotego Runa. Być może w tych przypadkach za informatora również posłużył Mikołaj Lasocki. Natomiast trzeba odrzucić wersję Kroniki Soboru w Konstancji, gdyż nie ma innego źródła poświadczającego taką kolorystykę. W tym miejscu dochodzi jeszcze kwestia podobieństwa herbów Grzymalitów i Pogorzelów. Zajmujący się tym zagadnieniem Tomasz Jurek nie umiał określić ich wzajemnego pokrewieństwa, ale według niego musiało ono istnieć, skoro oba rody pochodziły od komesa Jaracza, żyjącego w XII w. ${ }^{34}$ „Wszyscy Pogorzele pieczętowali się - i to już od połowy XIII w. - zamkiem z trzema wieżami, a więc tak samo, jak polscy Grzymałowie. Różnica zachodziła tylko w kolorystyce: herb Pogorzelów miał czerwony zamek w białym polu, Grzymała zaś biały zamek w polu czerwonym"35. Bardzo możliwe, że powtórzenie herbu Grzymalitów w Armorialu Lyncenich ( $\mathrm{nr} 18$ i 60) oraz w Kodeksie z Bergshammar (nr 26 i 67) oznaczać może właśnie Grzymałów i Pogorzelów. Także na fryzie heraldycznym w kaplicy św. Jakuba w Lądzie możemy mieć do czynienia $z$ herbem Pogorzelów, a nie, jak dotychczas sądzono, z Grzymalitami. J. Szymański nie uwzględnił tego problemu w swoim opisie oraz nie stworzył hasła z rodem Pogorzelów, co rzeczywiście nie wydaje się konieczne, choć niezbędne zdaje się przynajmniej zrobienie rozróżnienia między obydwoma rodami. Jakim więc kryterium kierował się J. Szymański przy opisywaniu tego herbu? Wybrał przecież w całości wariant z Armorialu Lyncenich oraz Kodeksu $z$ Bergshammar. Dlaczego nie zaufał polskiemu źródłu, które było najwierniejsze polskiej heraldyce? Zauważyć tu można kolejne nieścisłości i niekonsekwencje w badaniach tego uczonego.

Oczywiście wskazane błędy nie wyczerpują listy wszystkich pomyłek znajdujących się w tym dziele. Wybrałem możliwie najbardziej „reprezentatywne", na które się natknąłem, przeglądając herbarz. Rzecz jasna, moim celem nie było obniżenie wartości Herbarza średniowiecznego rycerstwa polskiego, gdyż jest to jedyna publikacja tego typu o charakterze naukowym. Oprócz niego warto zajrzeć do popularnonaukowej pracy Alfreda Znamierowskiego ${ }^{36}$, która, mimo że jest nowsza, nie dorównuje poziomem naukowym omawianemu herbarzowi. Tam też można zauważyć powielenie błędów zrobionych przez J. Szymańskiego. Myślę, że błędy popełnione przez niego, które znalazłem, nie wynikały z jego niewiedzy, lecz z prostych niedopatrzeń, co przy ogromie przebadanego materiału jest całkowicie zrozumiałe.

\footnotetext{
34 T. Jurek, Rodowód Pogorzelów, Kraków 2005, s. 21-25.

35 Ibidem, s. 22.

36 A. Znamierowski, Herbarz rodowy, Warszawa 2004.
} 


\section{Bibliografia}

\section{Źródła}

Das Concilium So zu Constantz gehalten ist worden Des jars do man zalt von der geburdt vnsers erlösers M.CCCC.XIII Jar [...], Augsburg 1483, http://tudigit. ulb.tu-darmstadt.de/show/inc-iii-55/ [dostęp: 9.11.2014].

DŁUGOSZ J., Catalogus Archiepiscoporum Gnesnensium, [w:] Joannis Dlugossii Senioris Canonici Cracoviensis Opera omnia, t. 1, wyd. I. Ż. Pauli, Kraków 1887.

Klejnoty Długoszowe, wyd. M. Friedberg, „Rocznik Polskiego Towarzystwa Heraldycznego we Lwowie" 1930, t. 10.

Kodeks dyplomatyczny Wielkopolski, wyd. I. Zakrzewski, t. 2-4, Poznań 18791881.

Le grand armorial équestre de la Toison d'or, http://gallica.bnf.fr/ark:/12148/btvlb 55009806h/ [dostęp: 9.11.2014].

Materyały do historyi prawa i heraldyki polskiej, wyd. B. Ulanowski, [w:] Scriptores rerum polonicarum, t. 9, Kraków 1886.

Starodawne prawa polskiego pomniki $z$ ksiag rękopiśmiennych dotąd nieużytych główniej zaś z ksiag dawnych sadowych ziemskich i grodzkich ziemi krakowskiej, t. 2, wyd. A. Z. Helcel, Warszawa 1870.

\section{Opracowania}

BENYSKIEWICZ K., Ród Jeleni Niałków i jego rola w procesie jednoczenia państwa polskiego na przełomie XIII i XIV w., Poznań 2002.

HEYMOWSKI A., Herby polskie w brukselskim Armorial Gymnich, recte Lyncenich, „Studia Źródłoznawcze” 1985, t. 29, s. 95-124.

HEYMOWSKI A., Herby polskie w sztokholmskim Codex Bergshammar, „Studia Źródłoznawcze" 1967, t. 12, s. 73-111.

GÓRSKA-GOŁASKA K., Dobra Nałęczów w Wielkopolsce w średniowieczu, "Studia i Materiały do Dziejów Wielkopolski i Pomorza” 1984, t. 15, z. 2, s. $177-218$.

JUREK T., Rodowód Pogorzelów, Kraków 2005.

Katalog zabytków sztuki w Polsce: województwo kieleckie, t. 3, z. 6, red. J. Łoziński, Warszawa 1958.

KRASIŃSKA M., KRASIŃSKI Z. A., European Bison. The Nature Monograph, Białowieża 2007.

LARCHEY L., Armorial ancien équestre de la Toison dior et de l'Europe au $X V^{\prime}$ siécle, Paris 1890.

ŁOJKO J., Fryz heraldyczny z kaplicy klasztornej Św. Jakuba w Lądzie nad Wartą, „Studia Źródłoznawcze” 1977, t. 22, s. 125-150. 
MAŁECKI A., Studya heraldyczne, t. 1-2, Lwów 1890-1891.

PAKULSKI J., Nałęcze wielkopolscy w średniowieczu, Toruń 1982.

PIEKOSIŃSKI F., Heraldyka polska, Lwów 1911.

PIEKOSIŃSKI F., Pieczęcie polskie wieków średnich, Kraków 1899.

POLACZKÓWNA H., Najstarsze źródła heraldyki polskiej, Lwów 1925.

SZYMAŃSKI J., Herbarz średniowiecznego rycerstwa polskiego, Warszawa 1993. ZNAMIEROWSKI A., Herbarz rodowy, Warszawa 2004. 